\title{
Endometriosis-Associated Pneumothorax with Hepatic Microherniations
}

\author{
Vadim G Pischilk ${ }^{1,2}$, Aleksandr D Obornev ${ }^{1 *}$ and Olga S Maslak ${ }^{2}$ \\ ${ }^{1}$ Clinical Hospital №122 named after LG Sokolov, Russia \\ ${ }^{2}$ Saint-Petersburg State University, Russia
}

Submission: January 09, 2019 ; Published: January 18, 2019

*Corresponding author: Aleksandr Obornev, Clinical Hospital №122 named after LG Sokolov, Russia

\begin{abstract}
We present a case of multiple liver microherniations due to endometriotic diaphragmatic defects in a woman with right-sided pneumothorax and bilateral Fallopian tube resection. A 33-yr old female patient was referred with moderate right-sided chest pain during previous 3 days. On CT-scan we observed a right-sided moderate pneumothorax. On the diaphragmatic dome some tissue nodules were observed. During VATS we observed liver tissue, protruding into the pleural cavity through the defects in the diaphragm. Resection of the tendinous portion was performed with separate suture closure of the diaphragm, added by costal pleurectomy. The patient was dispatched to the gynecologist for further treatment. After prescription of analogues of GNRH no sign of recurrence was seen. In our case no evidence of pulmonary abnormalities was seen, thus, excluding other ways of air passage to the pleural cavity. The only abnormal place was the diaphragmatic dome. Surprisingly, the patient underwent bilateral tube resection in 2010. CT-scan findings, which were firstly proposed to be of endometriotic origin, revealed during VATS as liver microherniatons.
\end{abstract}

Keywords: Catamenial pneumothorax; VATS; Thoracic endometriosis; Pleurectomy; Porous diaphragm

Abbreviatations: VATS: Video-Assisted Thoracic Surgery; GNRH: Gonadotropine-Releasing Hormone

\section{Introduction}

Thoracic endometriosis became an important cause of spontaneous pneumothorax in women in the last decades. This disease is thought to have some special features, such as rightsided localization, frequent recurrences, difficulties in early diagnosis and rather challenging surgical tactics to prevent recurrence. Trans diaphragmatic air passage theory is one of the most strong theories, describing the pathogenesis of this type of pneumothorax. Thus, several studies described multiple nodules on the diaphragmatic dome to be special signs of diaphragmatic endometriosis $[1,2]$.

We present a case of multiple liver microherniations due to endometriotic diaphragmatic defects in a woman with rightsided pneumothorax and bilateral Fallopian tube resection.

\section{Case Report}

A 33-yr old female patient was referred to our hospital with moderate right-sided chest pain during previous 3 days. She was in the second half of her menstrual cycle. On CT-scan we observed a right-sided moderate pneumothorax with most amount of air over the right hemidiaphragm. On the diaphragmatic dome some tissue nodules were observed (Figure 1).
The patient revealed similar complaints during menstruation for several previous months. We suspected endometriosisassociated pneumothorax. However, the patient underwent leftsided ovarioectomy with bilateral fallopian tube resection due to pelvic endometriosis in 2010. She experienced two unsuccessful attempts of extracorporeal fertilization in 2015,2016.

On the next day she underwent VATS. We found some adhesions between the lung and the chest wall, evidence of previous pneumothoraces. While examining the diaphragmatic dome, strong adhesions with lung basal surface and diaphragmatic perforations were noted (Figure 2).

There was no sign of macroscopic endometrial ectopies, but soft-tissue nodules, seen on CT were presented with liver tissue, protruding into the pleural cavity through the defects in the diaphragm (Figure 3). We meticulously dissected the perforated part of the tendinous dome with all defects. After removing of the dissected part, we revealed severely deformed surface of the liver (Figure 4). After that, the diaphragm was closed with separate sutures (Figure 5). We performed full costal pleurectomy to prevent recurrences (Figure 6). 


\section{Journal of Gynecology and Women's Health}
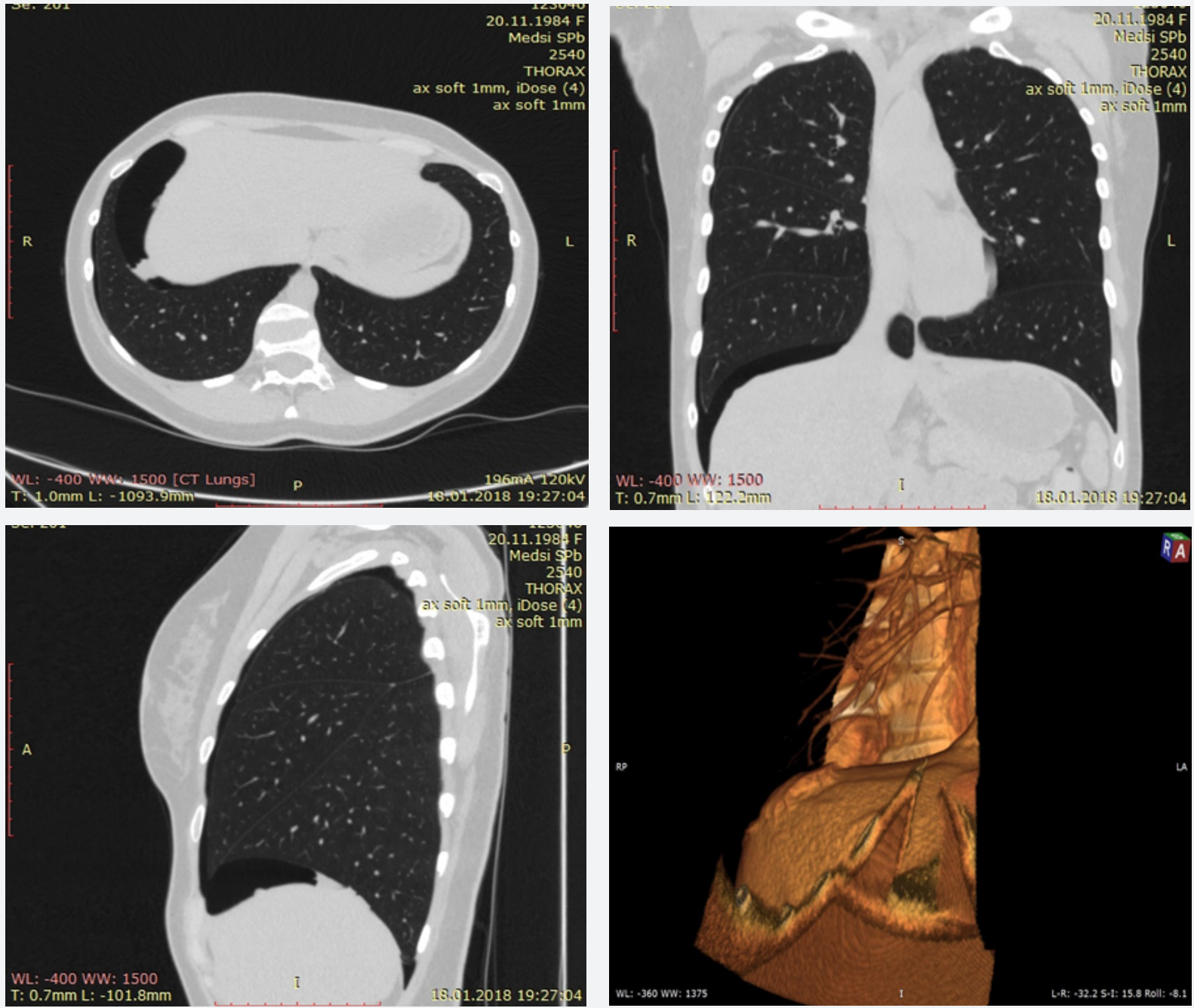

Figure 1: Diaphragmatic soft-tissue lesions and 3D-reconstruction.

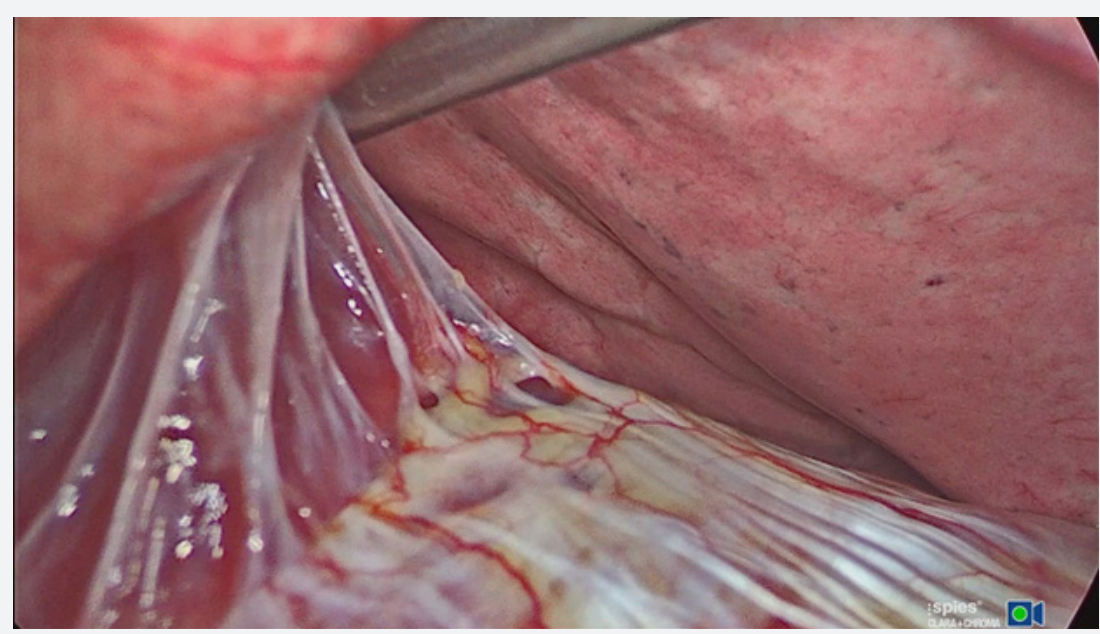

Figure 2: Adhesions between tendinous portion of the right hemidiaphragm with perforations and basal surface of the lung

Post operational period was uneventful. Pleural drain was removed on the third day. Patient was dismissed on the fourth day. Estrogen receptors were found on immunostaining, thus confirming the diagnosis of thoracic endometriosis. The patient was dispatched to the gynecologist for further treatment. 18 days after the operation there was a recurrence of small right-sided pneumothorax, that resolved spontaneously. After prescription of analogues of GNRH no sign of recurrence was seen. 


\section{Journal of Gynecology and Women's Health}
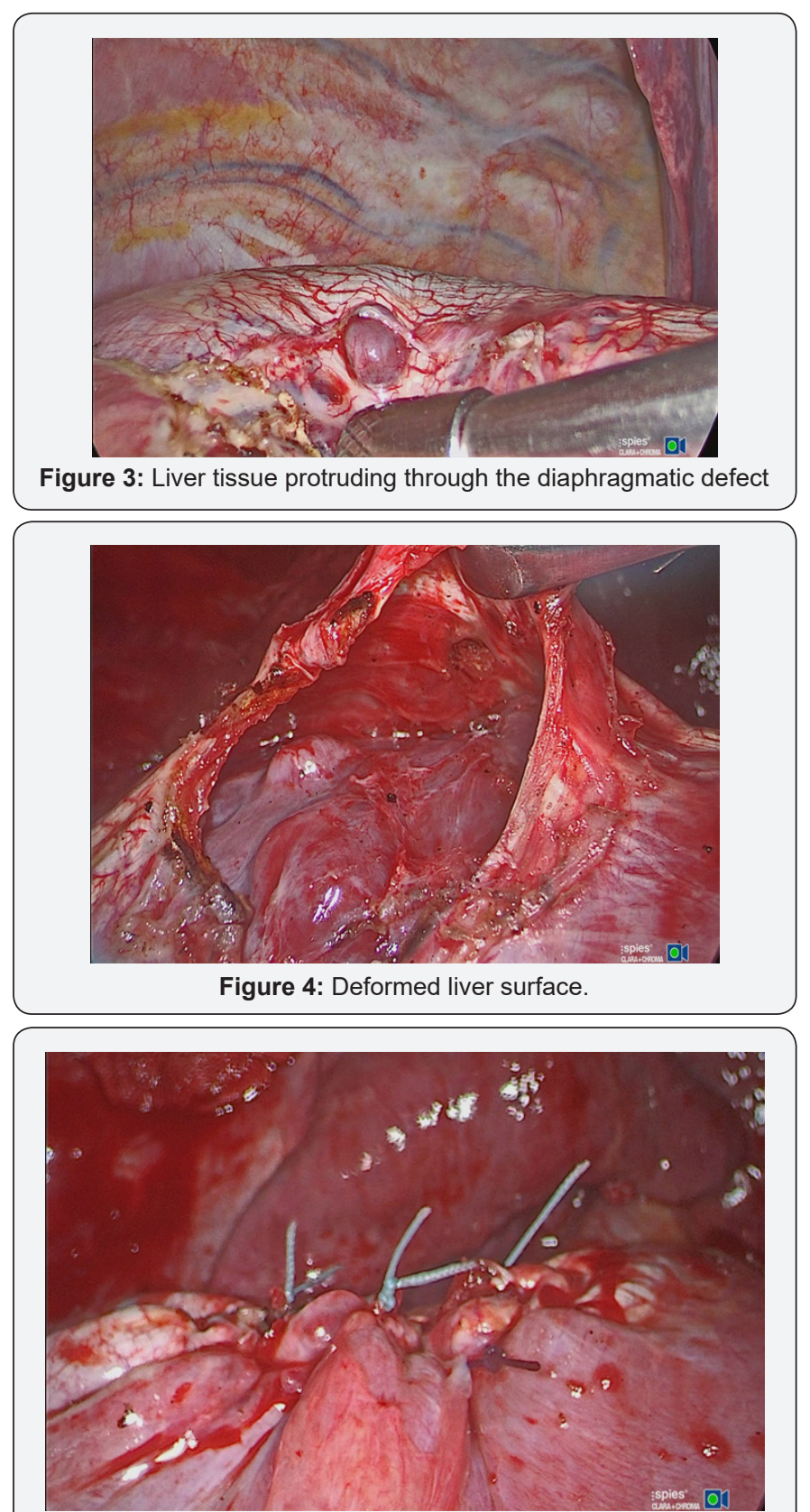

Figure 5: Repaired defect of the tendinous portion of the diaphragm.

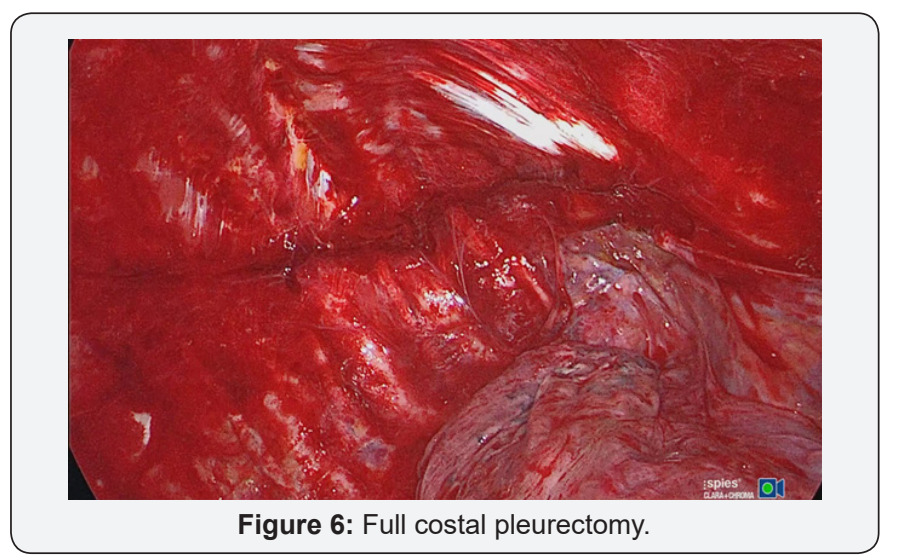

\section{Discussion}

According to recently published data, EAP is a considerable cause of secondary spontaneous pneumothorax in women. In all population of women with spontaneous pneumothorax it can comprise about $15 \%[3,4]$. The lack of specific clinical symptoms and necessity of careful visualisation of pleural cavity makes early diagnosis difficult $[1,5,6]$. The leading role in its pathogenesis, seems to belong to trans diaphragmatic passage of air to the pleural cavity. However, some cases show parenchymal endometriotic ectopies.

In our case no evidence of pulmonary abnormalities was seen, thus, excluding other ways of air passage to the pleural cavity. The only abnormal place was the diaphragmatic dome. Surprisingly, the patient underwent bilateral tube resection in 2010. However, previous unsuccessful attempts of extracorporeal fertilization made us propose endometriosis-associated etiology of this pneumothorax.

It seems that there was some kind of tube recanalization during those 7 years between two surgical events.

CT-scan findings, which were firstly proposed to be of endometriotic origin, revealed during VATS as liver microherniatons. The amount of air and its localization over the diaphragm is common for endometriosis-associated pneumothorax. MRI of the diaphragm, which is considered to be more specific in diagnosing endometriotic tissue than CT, was to our mind redundant, thus VATS can solve all the diagnostic and surgical problems.

Surgical treatment was performed according to most popular strategy nowadays $[4,7,8]$ : excluding of air passage via diaphragmatic defects and pleurectomy to prevent recurrences with further conservative treatment under supervision of the gynecologist. Thereby, thoracic endometriosis can be the only site of endometriosis, leading to "occult" infertility, undiagnosed in the absence of spontaneous pneomothoraces.

\section{References}

1. Visouli AN, Darwiche K, Mpakas A, Zarogoulidis P, Papagiannis A, et al (2012) Catamenial pneumothorax: a rare entity? Report of 5 casesand review of the literature. J Thorac Dis 4(suppl 1): 17-31.

2. Rousset P, Rousset-Jablonski C, Alifano M, Mansuet-Lupo A, Buy JN, et al. (2014) Thoracic endometriosis syndrome: CT and MRI features. Clin Radiol 69(3): 323-330.

3. Olive D, Pritts EA (2001) Treatment of Endometriosis. The New England Journal of Medicine 345: 266-275.

4. Ciriaco P, Negri G, Libretti L, Carretta A, Melloni G, et al. (2009) Surgical treatment of catamenial pneumothorax: a single centre experience. Interact Cardiovasc Thorac Surg 8(3): 349-352.

5. Athwal P, Patel K, Hassani C, Bahadori S, Nardi P, et al. (2013) A case of multisystem endometriosis. J Radiol Case Rep 7(10): 1-6.

6. Attaran S, Bille A, Karenovics W, Lang-Lazdunski L (2013) Video thoracoscopic repair of diaphragm and pleurectomy/abrasion in patients with catamenial pneumothorax. A 9-year experience. Chest 143(4): 1066-1069. 
7. Alifano M, Jablonski C, Kadiri H, Falcoz P, Gompel A, et al. (2007) Catamenial and Noncatamenial, Endometriosis-related or Nonendometriosis-related Pneumothorax Referred for Surgery. Am J Respir Crit Care Med 176(10): 1048-1053.
8. Bobbio A, Trisolini R, Damotte D, Alifano M (2011) Thoracic endometriosis and catamenial pneumothorax. Eur Respir Mon 54: 265-281. Sefrioui O, Madkour A, Aboulmaouahib S, Louanjli KIN (2018) Women with extreme low AMH values could have in vitro fertilization success. Gynecol Endocrinol 16:1-4.

\section{Your next submission with Juniper Publishers will reach you the below assets}

- Quality Editorial service

- Swift Peer Review

- Reprints availability

- E-prints Service

- Manuscript Podcast for convenient understanding

- Global attainment for your research

- Manuscript accessibility in different formats ( Pdf, E-pub, Full Text, Audio)

- Unceasing customer service

Track the below URL for one-step submission https://juniperpublishers.com/online-submission.php 